BMC

Complementary \& Alternative Medicine

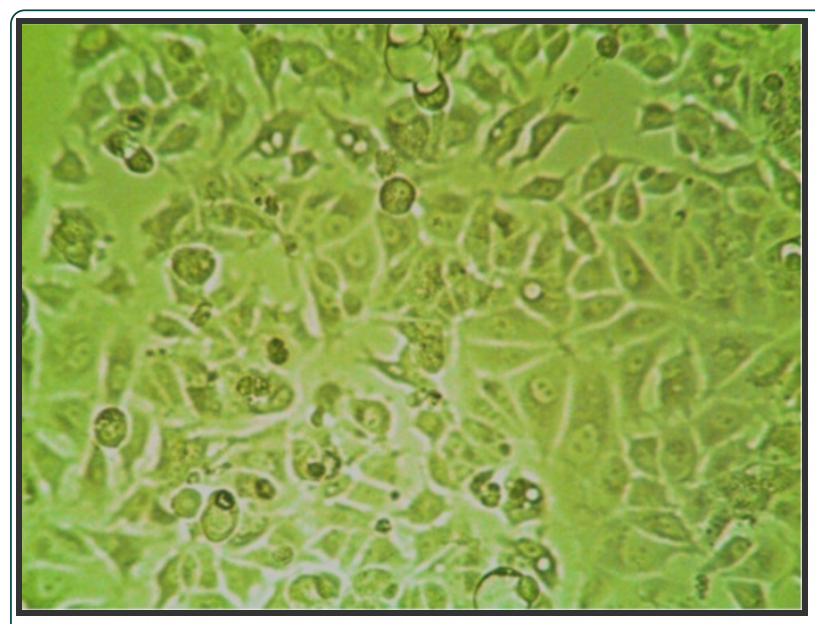

A

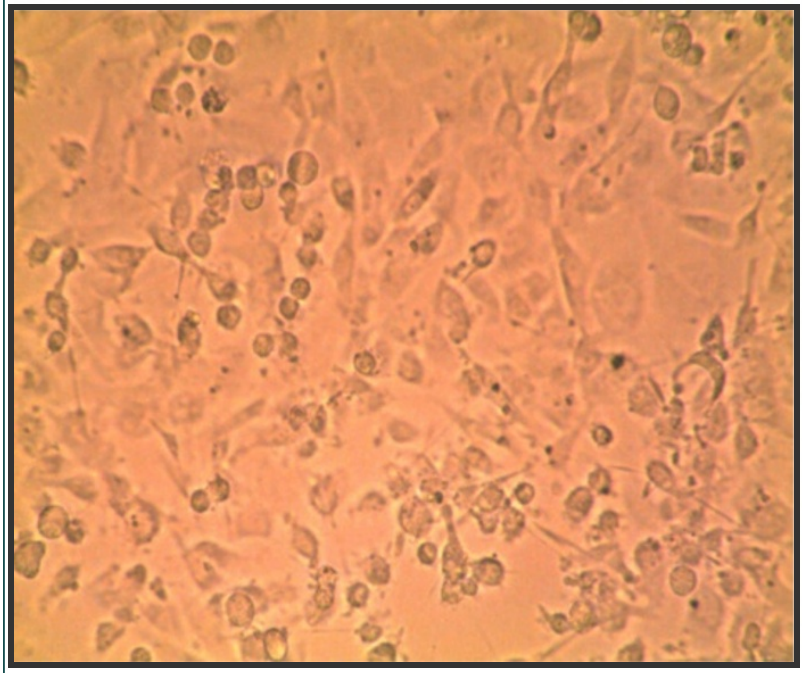

C

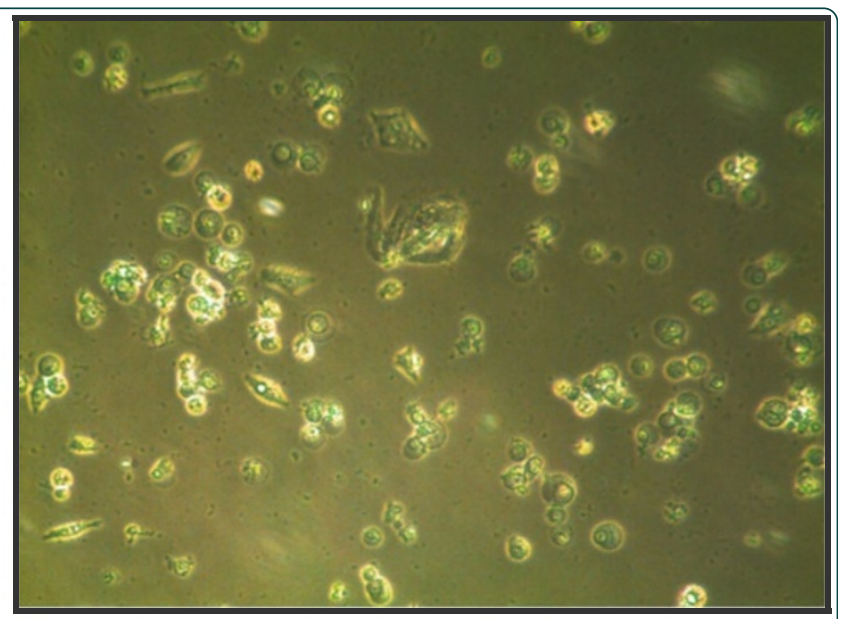

B

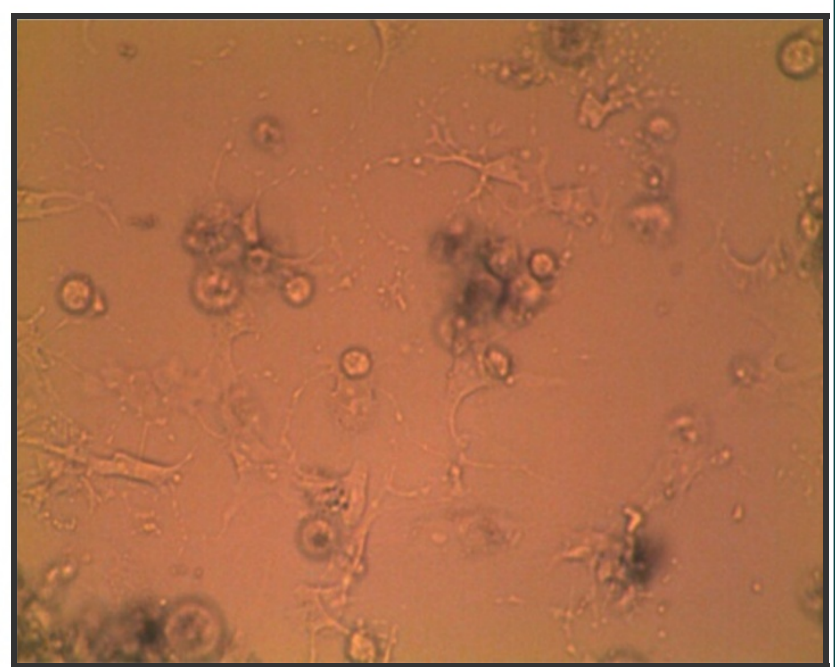

D

Erythrophleum suaveolen $\left(\mathrm{IC}_{50}=0.2-1.3 \mu \mathrm{g} / \mathrm{mL}\right)$

\title{
In vitro anticancer screening of 24 locally used Nigerian medicinal plants
}

Fadeyi et al. 


\title{
In vitro anticancer screening of 24 locally used Nigerian medicinal plants
}

\author{
Saudat Adamson Fadeyi ${ }^{1,3}$, Olugbeminiyi O Fadeyi ${ }^{2,4}$, Adedeji A Adejumo ${ }^{5}$, Cosmas Okoro ${ }^{2}$ \\ and Elbert Lewis Myles ${ }^{1 *}$
}

\begin{abstract}
Background: Plants that are used as traditional medicine represent a relevant pool for selecting plant candidates that may have anticancer properties. In this study, the ethnomedicinal approach was used to select several medicinal plants native to Nigeria, on the basis of their local or traditional uses. The collected plants were then evaluated for cytoxicity.

Methods: The antitumor activity of methanolic extracts obtained from 24 of the selected plants, were evaluated in vitro on five human cancer cell lines.

Results: Results obtained from the plants screened indicate that 18 plant extracts of folk medicine exhibited promising cytotoxic activity against human carcinoma cell lines. Erythrophleum suaveolens (Guill. \& Perr.) Brenan was found to demonstrate potent anti-cancer activity in this study exhibiting $I C_{50}=0.2-1.3 \mu \mathrm{g} / \mathrm{ml}$.

Conclusions: Based on the significantly potent activity of some plants extracts reported here, further studies aimed at mechanism elucidation and bio-guided isolation of active anticancer compounds is currently underway.
\end{abstract}

Keywords: Nigeria, Anti-cancer, Ethnomedicine, Cytotoxic activity

\section{Background}

Currently, one in four deaths in the United States is due to cancer [1]. When ranked within age groups, cancer is one of the five leading causes of death amongst both males and females and the single largest cause of death worldwide [1]. By 2015 cancer morbidity may climb to around nine million world-wide. This growing trend indicates deficiency in the present cancer therapies which include surgical operation, radiotherapy and chemotherapy. Since the average survival rates have remained essentially unchanged despite such aggressive treatments, there is a critical need for anti-cancer agents with higher efficacy, and less side effects that can be acquired at an affordable cost.

We suppose that plants are the best alternative, as they provide an inexhaustible pool of efficacious agents for treating disease. Phytochemicals have always been sought after because of their inherent potential to cure

\footnotetext{
* Correspondence: emyles@tnstate.edu

${ }^{1}$ Department of Biological Sciences, Tennessee State University, 3500 John A. Merritt Blvd, Nashville, TN 37217, USA

Full list of author information is available at the end of the article
}

disease, as demonstrated by ancient medicinal practices [2-5]. Furthermore, several plants have been shown to be sources of therapeutically important agents, valuable in the treatment of cancer. For instance, there are very effective cancer chemotherapeutic drugs that have been derived from natural origin [6]. These include plantderived agents, such as the vinca alkaloids vinblastine and vincristine, isolated from the Madagascar periwinkle, Catharanthus roseus (L.) G. Don. [7]; paclitaxel (Taxol), originally isolated from the bark of the Pacific yew tree from the Pacific Northwest, Taxus brevifolia Nutt., and the analogue, docetaxel [8]; etoposide and teniposide, derived semisynthetically from epipodophyllotoxin, an epimer of podophyllotoxin, isolated from roots of Podophyllum species [9]; and camptothecin, isolated from the bark of Camptotheca acuminata Decne., a precursor to the semisynthethetic drugs topotecan (Hycamptin) and irinotecan (Camptosar) [10].

There are estimated to be between 200,000 and 450,000 species of tropical flowering plants within our biosphere, with the greatest plant diversity being found in the moist tropics $[11,12]$. The approaches for selecting 
plants to be tested for new bioactive compounds range from random selection to ethnopharmalogical approaches relying on knowledge gained from traditional medicine usage. Traditional medicine occupies a central role in the developing nations [13].

Although there have been vast discoveries of potent cytotoxic agents attributed to Asian and Ayurvedic Indian traditional medicine, the need for this study is derived from the fact that much of the medicinal plants found in Africa are unexplored. Drug discovery of African plants is of relevant interest because Africa hosts 57,704 species of the world's flora [14] and although Africans use over 5000 of their plants for medicinal purposes, the study of African medicinal plants has not been accredited or documented as extensively as the Chinese and Indian herbal medicines [13,15]. The potential of Nigerian flora in particular, as a veritable source for pharmaceuticals and other therapeutic materials has been well documented [16]. In the present study, we performed the preliminary screening of 24 methanolic plant extracts, used in Nigerian folk medicine, to identify plants with cytotoxic activity against five human cancer cell lines.

\section{Methods}

Collection of plant material and preparation of extracts

Plant materials (the list of plants studied is given in Table 1) were obtained by Mr A. A Adejumo at different

Table 1 List of plants screened in this study and their report local uses

\begin{tabular}{|c|c|c|c|c|}
\hline Species & Family & $\begin{array}{l}\text { Voucher specimen } \\
\text { (Part used) }\end{array}$ & Reported local medicinal uses & $\begin{array}{l}\text { Extract } \\
\text { yield }(\%)\end{array}$ \\
\hline $\begin{array}{l}\text { Acanthus montanus (Nees) } \\
\text { T. Anders }\end{array}$ & Acanthacease & TVN-A08 (l,r,S) & $\begin{array}{l}\text { Syphilis, emetic, urethral discharge, } \\
\text { purgative [17] }\end{array}$ & 4.05 \\
\hline Allanblackia floribunda Oliv. & Guttiferae & TVN-A33 $(l, b, r, f)$ & Malaria, dysentery [18] & 4.63 \\
\hline Amaranthus spinosus L. & Amaranthaceae & TVN-A04 (l,st) & Diarrhea, dysentery, Gonorrhea [18] & 6.76 \\
\hline Bidens pilosa L. & Compositae & TVN-A75 (l,b,st) & Antidiabetic, anaesthetic [19] & 8.64 \\
\hline Bryophyllum pinnatum Lam. & Crassulaceae & TVN-A64 (I) & Respiratory tract infections, antibacterial [20] & 1.54 \\
\hline Byrsocarpus coccineus Schumach & Connaraceae & TVN-A14 (b,l) & $\begin{array}{l}\text { Jaundice, pile, gonorrhea, venereal disease, } \\
\text { impotence [21] }\end{array}$ & 5.79 \\
\hline Cajanus cajan L. & Leguminosae & TVN-A09 (I) & Smallpox, chicken pox, malaria $[18,22]$ & 4.08 \\
\hline Capsicum frutescens $\mathrm{L}$. & Solanaceae & TVN-A03 (f,s) & Malaria, Fever, dysentery [18] & 1.94 \\
\hline $\begin{array}{l}\text { Chromolaena odorata (L.) } \\
\text { R.M. King \& H. Rob. }\end{array}$ & Rosaceae & TVN-A02 (l,st,r) & Malaria, antimicrobial $[18,23]$ & 9.19 \\
\hline $\begin{array}{l}\text { Crassocephalum crepidioides } \\
\text { (Benth.) S. Moore. }\end{array}$ & Compositae & TVN-A34 $(I, r, S, f)$ & Indigestion, stomach ache, headache [24] & 6.38 \\
\hline Daniellia oliveri Hutch \& Dalz. & Leguminosae & TVN-A11 (I) & $\begin{array}{l}\text { Backache, headache, antibacterial, } \\
\text { yellow fever [25] }\end{array}$ & 5.47 \\
\hline $\begin{array}{l}\text { Erythrophleum suaveolens } \\
\text { (Guill. \& Perr.) Brenan }\end{array}$ & Leguminosae & TVN-A65 (b) & $\begin{array}{l}\text { Poison, cardiac problems, venom intoxication, } \\
\text { inflammatory diseases [22] }\end{array}$ & 12.47 \\
\hline Hoslundia opposita Vahl. & Labiatae & TVN-A72 (I) & $\begin{array}{l}\text { Abdominal pains, epilepsy, neurotic } \\
\text { disorders [26] }\end{array}$ & 5.82 \\
\hline Jatropa curcas L. & Euphorbiaceae & TVN-A19 (I) & Ringworm, eczema, ulcer [18] & 1.31 \\
\hline Landolphia dulcis Var. & $\begin{array}{l}\text { Barteri } \\
\text { Apocynaceae }\end{array}$ & TVN-A07 (b) & $\begin{array}{l}\text { Rheumatism, cough, kidney diseases, } \\
\text { antibacterial [27] }\end{array}$ & 5.75 \\
\hline Lannea nigritana (Sc. Elliot) Keay. & Anacardaceae & TVN-A61 $(I, b, r)$ & None & 5.09 \\
\hline Ocimum basilicum L. & Lamiaceae & TVN-A10 (I) & $\begin{array}{l}\text { Gonorrhea, catarrhal conditions, cough, } \\
\text { anthelmintics [28] }\end{array}$ & 9.7 \\
\hline Parkia biglobosa (Jacq.) G. & $\begin{array}{l}\text { Don. } \\
\text { Leguminosae }\end{array}$ & TVN-A01 (I) & Malaria, fever [18,23] & 3.87 \\
\hline Parkia filicoidea Welw. & Mimosaceae & TVN-A35 (l,st) & None & 7.02 \\
\hline Pterocarpus santalinoides DC. & Fabaceae & TVN-A06 (l,st) & Insecticidal, larvicidal $[17,29,30]$ & 3. 34 \\
\hline Rauvolfia vomitoria Afzel. & Apocynaceae & TVN-A28 (b) & $\begin{array}{l}\text { Sedative/mental disorder, antidiabetic, } \\
\text { malaria }[19,23]\end{array}$ & 6.61 \\
\hline Sida acuta Burm. F. & Malvaceae & TVN-A77 (l,st) & Malaria, ulcer, fever [18] & 2.47 \\
\hline Tetrapleura tetraptera Taub. & Leguminosae & TVN-A73 $(I, r, S, f)$ & Sickle cell [31] & 10.52 \\
\hline Vitex doniana Sw. & Verbenaceae & TVN-A16 (b,r) & Gastroenteritis, diarrhea, antimicrobial [32] & 26.75 \\
\hline
\end{tabular}

Plant parts are denoted as follows: $1=$ leaves, $b=$ Bark $s t=$ Stem, $s=$ Seeds, $r=$ Roots. 
times of the year. Specimens were collected from the western part of Nigeria (Lagos, Ogun, Oyo and Osun states) from traditional healers and indigenous herbal merchants. Collected specimens were authenticated by comparison with corresponding herbarium specimens. Some samples have been deposited at the Department of Biological Science, Tennessee State University, Nashville, Tennessee, USA.

Plant materials were air dried and separate extracts were made from the leaves, seeds, stems and bark portions, respectively. The methanolic extracts were prepared by immersing portions of the whole plant (200 g) in 500-1000 $\mathrm{ml}$ of methanol at room temperature $\left(25^{\circ} \mathrm{C}\right)$ and stirred for 6 days. The crude extracts were filtered and the filtrate evaporated using a rotary evaporator. The dissolved constituents were further dried under pressurized vacuum conditions. Stock solutions were prepared by dissolving the dried residue in dimethyl sulphoxide (DMSO). Extract solutions were stored at $-20^{\circ} \mathrm{C}$ until use.

\section{Cell lines}

The six selected cancer cell lines used in this research were derived from human breast adenocarcinoma MCF7 (ATCC No. HTB-22), BT-20 (ATCC No. HTB-19), BT-549 (ATCC No. HTB-122), prostate adenocarcinoma PC-3 (ATCC No. CRL-1435), acute T cell leukemia Jurkat (ATCC No. TIB-152), and colon adenocarcinoma SW-480 (ATCC No. CCL-228) cells were provided by American Type Culture Collection (Rockville, MD). These cells were grown in RPMI-1640, with the exception of MCF-7, which was grown in Dulbecco's modified eagle medium (DMEM); all supplemented with $10 \%$ heat inactivated fetal bovine serum (FBS), $2 \mathrm{mM}$ L-glutamine, and $1 \%$ penicillin-streptomycin. DMEM was also supplemented with $0.01 \mathrm{mg} / \mathrm{ml}$ insulin and $1 \mathrm{mM}$ sodium pyruvate. Cells were incubated in a $5 \% \mathrm{CO}_{2}$ humidified incubator at $37^{\circ} \mathrm{C}$ and passaged bi-weekly.

\section{Trypan blue exclusion viability assay}

Anticancer activity was determined using this assay to measure cell viability [28]. MCF-7, BT-20, BT-549, PC-3, JURKAT and SW-480 cell lines were plated at densities of $1 \times 10^{5}$ and $5 \times 10^{4}$ per well in 12-well and 24-well tissue culture plates, respectively. Cells were incubated at $37^{\circ} \mathrm{C}$ and $5 \% \mathrm{CO}_{2}$ for $24 \mathrm{~h}$, after which the cells received treatment with fresh medium supplemented with extracts at concentrations ranging between $0.01 \mu \mathrm{g} / \mathrm{ml}$ $200 \mu \mathrm{g} / \mathrm{ml}$, for a total volume of $1 \mathrm{ml}-2 \mathrm{ml}$ per well in 24 and 12-well plate formats, respectively. The negative controls received fresh medium supplemented with the experimental vehicle, DMSO only. Following $72 \mathrm{~h}$ of incubation at $37^{\circ} \mathrm{C}$, the cells were trypsinized with $0.25 \%$ trypsin-EDTA solution. Cells were then resuspended in phosphate buffer saline (PBS) and stained with $0.4 \%$ Trypan blue dye solution ( $\mathrm{v} / \mathrm{v}$ in PBS). Live cells are excluded from the stain while dead cells absorb the stain appearing blue in color under a light microscope enabling the enumeration of viable cells. Cell counts were expressed as mean \pm standard deviation (SD), representative of three separate experiments.

\section{AlamarBlue $^{\mathrm{TM}}$ Metabolic assay}

This assay incorporates a fluorometric/colorimetric growth indicator based on detection of metabolic activity in which living cells yield a very strong fluorescent product [33]. MCF-7, BT-20, BT-549, PC-3, Jurkat, and SW480 cell lines were plated at $1 \times 10^{4}$ cells per well in a 96-well black plate and stabilized in medium at $37^{\circ} \mathrm{C}$ and $5 \% \mathrm{CO}_{2}$ for $24 \mathrm{~h}$. Following the first $24 \mathrm{~h}$, cells received fresh medium supplemented with test extracts at final concentrations ranging between $0.01 \mu \mathrm{g} / \mathrm{ml}-200 \mu \mathrm{g} /$ $\mathrm{ml}$, in a total volume of $200 \mu \mathrm{l}$ per well. The negative control received the experimental vehicle DMSO at the same end-concentration of $0.1 \%$. Cytotoxicity as indicated by a reduction in cellular metabolic activity was assayed at 72 h, using AlamarBlue ${ }^{\mathrm{TM}}$ (Invitrogen); $20 \mu \mathrm{l}$ of alamar blue dye (end-concentration of $10 \%$ ) was added to each well and the plates incubated at $37^{\circ} \mathrm{C}$ overnight. The plates were then analyzed for fluorescence (F) using the SpectraMax Gemini EM microtiter plate reader at dual wavelengths (560 $\mathrm{nm} \lambda$ excitation, $590 \lambda \mathrm{nm}$ emission). SoftMax Pro 4.7.1 was used to analyze the data. The following formula was used to calculate the inhibition of cell growth: inhibition $(\%)=(1-$ mean $\mathrm{F}$ value of treatment group/mean F value of control) $\times 100$.

\section{Statistical analysis}

Quantitative values obtained per treatment were converted to percentage inhibition. Regression analysis was used to compute the inhibition concentration required to produce a $50 \%$ reduction in cell viability $\left(\mathrm{IC}_{50}\right)$. Results were expressed as the mean \pm SD of values obtained in triplicate from three independent experiments. Statistical differences between correlated samples were evaluated using Student's $t$-test and noted to be significantly different where $\mathrm{p}<0.05$. Composite treatments were compared using one-way analysis of variances (ANOVA) and considered significantly different where probability values were found to be equal to or less than 0.05 .

\section{Results and discussion}

Samples collected in this study were selected to include plants that have suggested bioactivity on the basis of their non-reported traditional usage as medicines. The following selected plants have been reported to be used in traditional treatments for various diseases and ailments ranging from headache, fever, throat and neck 
ailments, tonsillitis, cough, bronchitis, asthma, tuberculosis, pneumonia, constipation, hernia, dysentery, diarrhea; diseases due to infections from intestinal worm, filarial; venereal diseases such as gonorrhea, syphilis; diseases of the skin like leprosy, ulcers, sores, boils and other bacterial infections; also systemic diseases, malaria, yellow fever, measles, and small pox; as well as epilepsy, cardiovascular disease, diabetes, high blood pressure, inflammatory conditions and other diseases of liver, kidney, muscle and bone. This resulted in a set of 24 crude methanolic extracts from collected plants shown in Table 1.

The major aim of this study was to identify potential anticancer extracts that were effective, not by virtue of high concentration alone, rather by specific activity demonstrated even at low doses. In order to achieve this aim, the maximum test concentration was set at $200 \mu \mathrm{g} /$ $\mathrm{ml}$, as the criteria for identifying plants with potent activity within range. Using this criterion, plants with less than $50 \%$ inhibitory activity within the test range were excluded from further screening. Although such plants may likely demonstrate greater cytotoxicity at higher concentrations, the focus in this study was limited to plant extracts that caused substantial growth inhibition in a given cell line within the test concentration range of $<200 \mu \mathrm{g} / \mathrm{ml}$. The assumption was that such activity elicited in the plants' crude state would be indicative of even greater potent effects in the purified state. As a preliminary means of initially identifying extracts with activity, the effects of treatment were evaluated in vitro, in a two dose assay testing lower and upper concentrations of 20 and $200 \mu \mathrm{g} / \mathrm{ml}$ against human carcinoma cell lines. All cytotoxic activity was assessed at $72 \mathrm{~h}$ following

Table 2 Percent inhibiton values of plants crude extracts on three human cancer cell lines at 20 and $200 \mu \mathrm{g} / \mathrm{ml}$ concentrations

\begin{tabular}{|c|c|c|c|c|c|c|}
\hline \multirow[t]{2}{*}{ Species } & \multicolumn{2}{|l|}{ T-549 } & \multicolumn{2}{|l|}{ BT-20 } & \multicolumn{2}{|l|}{ PC-3 } \\
\hline & $20 \mu \mathrm{g} / \mathrm{ml}$ & $200 \mu \mathrm{g} / \mathrm{ml}$ & $20 \mu \mathrm{g} / \mathrm{ml}$ & $200 \mu \mathrm{g} / \mathrm{ml}$ & $20 \mu \mathrm{g} / \mathrm{ml}$ & $200 \mu \mathrm{g} / \mathrm{ml}$ \\
\hline Acanthus montanus & $7 \pm 5.01$ & $10 \pm 3.45$ & $\mathrm{Nd}$ & $27 \pm 8.38^{*}$ & $\mathrm{Nd}$ & $<5$ \\
\hline Allanblackia floribunda & $66 \pm 6.51^{*}$ & $96 \pm 3.48^{*}$ & $21 \pm 4.55$ & $80 \pm 5.38^{*}$ & $13 \pm 0.58$ & $92 \pm 5.29^{*}$ \\
\hline Amaranthus spinosus & $16 \pm 3.86$ & $<5$ & $8 \pm 1.72$ & $32 \pm 8.14$ & $\mathrm{Nd}$ & $\mathrm{Nd}$ \\
\hline Bidens pilosa & $23 \pm 9.50$ & $97 \pm 1.63^{*}$ & $\mathrm{Nd}$ & $93 \pm 1.73^{*}$ & $35 \pm 1.08$ & $95 \pm 1.53$ \\
\hline Bryophyllum pinnatum & $24 \pm 6.08$ & $96 \pm 1.68^{*}$ & $\mathrm{Nd}$ & $81 \pm 6.51^{*}$ & $\mathrm{Nd}$ & $95 \pm 1.62^{*}$ \\
\hline Byrsocarpus coccineus Bark & $20 \pm 2.51$ & 100 & $\mathrm{Nd}$ & $93 \pm 2.66^{*}$ & $\mathrm{Nd}$ & $97 \pm 6.15^{*}$ \\
\hline Leaves & $54 \pm 1.76$ & 100 & $\mathrm{Nd}$ & 100 & $\mathrm{Nd}$ & 100 \\
\hline Cajanus cajan & $9 \pm 1.46$ & $99 \pm 0.58^{*}$ & $<5$ & $99 \pm 0.17^{*}$ & $23 \pm 1.53$ & 100 \\
\hline Capsicum frutescens & $<5$ & $10 \pm 0.96$ & $<5$ & $39 \pm 3.96$ & $11 \pm 2.40$ & $41 \pm 1.08$ \\
\hline Chromolaena odorata & $13 \pm 4.21$ & $8 \pm 3.06$ & $6 \pm 0.81$ & $39 \pm 2.12$ & $\mathrm{Nd}$ & $\mathrm{Nd}$ \\
\hline Crassocephalum crepidioides & $14 \pm 2.14$ & $51 \pm 1.04^{*}$ & $\mathrm{Nd}$ & $10 \pm 5.21$ & $\mathrm{Nd}$ & $9 \pm 1.01$ \\
\hline Daniellia oliveri & $35 \pm 1.55$ & $97 \pm 0.21^{*}$ & $<5$ & $66 \pm 4.16^{*}$ & $22 \pm 10.50$ & $47 \pm 5.78$ \\
\hline Erythrophleum suaveolens & 100 & 100 & 100 & 100 & 100 & 100 \\
\hline Hoslundia opposita & $19 \pm 0.55$ & $96 \pm 0.42^{*}$ & $\mathrm{Nd}$ & $93 \pm 1.67^{*}$ & $\mathrm{Nd}$ & $51 \pm 8.21^{*}$ \\
\hline Jatropa curcas & $45 \pm 4.01$ & 100 & $29 \pm 0.61$ & $87 \pm 1.52^{*}$ & $\mathrm{Nd}$ & $\mathrm{Nd}$ \\
\hline Landolphia dulcis & $83 \pm 1.39$ & 100 & $\mathrm{Nd}$ & $11 \pm 1.21$ & $\mathrm{Nd}$ & $9 \pm 3.11$ \\
\hline Lannea nigritana & $32 \pm 0.32$ & $90 \pm 0.17^{*}$ & $\mathrm{Nd}$ & $\mathrm{Nd}$ & $\mathrm{Nd}$ & $21 \pm 7.71^{*}$ \\
\hline Ocimum basilicum & $<5$ & $<5$ & $<5$ & $<5$ & $<5$ & $\mathrm{Nd}$ \\
\hline Parkia biglobosa & $<5$ & $75 \pm 3.36^{*}$ & $7 \pm 5.13$ & $72 \pm 0.61$ & $17 \pm 7.21$ & $93 \pm 6.03^{*}$ \\
\hline Parkia filicoidea & $<5$ & $67 \pm 3.06^{*}$ & $<527 \pm 3.70$ & $10 \pm 0.70$ & $76 \pm 1.53^{*}$ & \\
\hline Pterocarpus santalinoides & $17 \pm 2.52$ & $98 \pm 0.45^{*}$ & $<5$ & $11 \pm 5.03$ & $<5$ & $17 \pm 0.40$ \\
\hline Rauvolfia vomitoria & $<537 \pm 1.12$ & $19 \pm 0.72$ & $33 \pm 1.71$ & $<5$ & $8 \pm 4.23$ & \\
\hline Sida acuta & $91 \pm 5.86^{*}$ & $95 \pm 3.16^{*}$ & $25 \pm 5.03$ & $97 \pm 0.57^{*}$ & $27 \pm 2.20$ & $97 \pm 1.80^{*}$ \\
\hline Tetrapleura tetraptera & $66 \pm 1.38^{*}$ & $10058 \pm 9.13^{*}$ & 100 & $\mathrm{Nd}$ & $\mathrm{Nd}$ & \\
\hline Vitex doniana Bark & $<5$ & $89 \pm 1.27^{*}$ & $\mathrm{Nd}$ & $55 \pm 1.33$ & $\mathrm{Nd}$ & $<5$ \\
\hline Root & $21 \pm 1.46$ & $56 \pm 2.35^{*}$ & $\mathrm{Nd}$ & $61 \pm 1.06$ & $\mathrm{Nd}$ & $57 \pm 1.25$ \\
\hline
\end{tabular}

The antiproliferative/cytotoxic effect is expressed in terms of the percent inhibition of cells growth relative to the DMSO control after $72 \mathrm{~h}$ exposure to the extracts. Results are expressed as mean \pm SD of three rreplicate experiments. $\mathrm{Nd}=$ Not determined. ${ }^{*}$ There was a significant difference in cell inhibition in extract-treated cultures compared with DMSO-control in all cell lines $(\mathrm{P}<0.05)$. 
treatment. The Trypan blue exclusion method and the AlamarBlue $^{\mathrm{TM}}$ metabolic assay were utilized to quantify cytotoxic or cytostatic effects.

Overall cytoxicity varied between extracts and between cell lines. Table 2 shows the percent inhibition of treated cells relative to the untreated controls. Initially, plants were screened individually against one or more cancer types from the panel of cell lines consisting of BT-549 (breast carcinoma), BT-20 (breast carcinoma) and PC-3 (prostate carcinoma). Then leads for secondary screening were selected on the basis of inhibition $\geq 50 \%$ at concentrations below the set upper limit tested. Plants that were considered moderately active showed cytoxicity $\geq 80 \%$ inhibition at $200 \mu \mathrm{g} / \mathrm{ml}$, however some of these plants were weakly cytotoxic at $20 \mu \mathrm{g} / \mathrm{ml}$. Very active extracts showed $50 \%$ or greater inhibition at $20 \mu \mathrm{g} /$ $\mathrm{ml}$, these plants were selected for further screening at a wider range of concentrations. Extracts exhibiting $\geq 80 \%$ inhibition at $20 \mu \mathrm{g} / \mathrm{ml}$ were considered potent and identified as prime targets for further screening.

Based on these criteria, 12 of these plants were categorized as moderately active. There were 6 plants that were considered very active to potent at least against one cancer cell line, these included Byrsocarpus coccineus with $54 \%$ inhibition at $20 \mu \mathrm{g} / \mathrm{ml}$ (against BT-549), Allanblackia floribunda and Tetrapleura tetraptera which both exhibited the lowest inhibition of $66 \%$ at 20 $\mu \mathrm{g} / \mathrm{ml}$ in this category (against BT-549). Landolphia dulcis and Sida acuta showed between $83 \%-91 \%$ at 20 $\mu \mathrm{g} / \mathrm{ml}$ (against BT-549) and the most potent was Erythrophleum suaveolens, exihibiting 100\% inhibition at $20 \mu \mathrm{g} / \mathrm{ml}$. In terms of potency between cell lines, Erythrophleum suaveolens showed the most consistent activity, causing total growth inhibition of all three cell lines, BT-549, BT-20 and PC-3. The latter were analyzed comprehensively in the second phase of screening. Amongst the plants that were moderately active, there is a trend of selectivity towards BT-549. Allanblackia floribunda showed significant variation at $20 \mu \mathrm{g} / \mathrm{ml}$, inhibiting BT- 549 by $66 \%$, but only $21 \%$ and $13 \%$ of BT-20 and PC-3 respectively. Similarly, amongst the very active plants, Sida acuta caused $91 \%$ inhibition of BT549 viability at $20 \mu \mathrm{g} / \mathrm{ml}$, however the same concentration resulted in only $25 \%$ and $27 \%$ inhibition of BT- 20 and $\mathrm{PC}-3$, respectively.

In Table 3, regression analysis was done to compute the inhibition concentration required to produce a $50 \%$ reduction in cell viability $\left(\mathrm{IC}_{50}\right)$ of the plant extracts $\left(R^{2} \geq 0.9\right)$. The concentration that causes $50 \%$ inhibition of the cancer cells by the crude extract of the Nigerian plants species investigated are displayed in Table 3 . The solvent extracts of 4 plants showed moderate $\mathrm{IC}_{50}$ value ranging from 62.5-177.3 $\mu \mathrm{g} / \mathrm{ml}$ (Table 3) against different cancer cell lines. Among them is the bark of Vitex

Table 3 IC50 $(\mu \mathrm{g} / \mathrm{mL})$ values for the in vitro cytotoxic activity of plants crude extracts on five human cancer cell lines

\begin{tabular}{|c|c|c|c|c|c|}
\hline Species & BT-549 & BT-20 & PC-3 & SW-480 & JURKAT \\
\hline Allanblackia floribunda & $14.7 \pm 0.23$ & $48.3 \pm 2.90$ & $29.4 \pm 0.69$ & $57.1 \pm 1.16$ & $\mathrm{Nd}$ \\
\hline Bidens pilosa & $43.1 \pm 6.09$ & $53.7 \pm 2.16^{*}$ & $47.7 \pm 2.69^{*}$ & $\mathrm{Nd}$ & $75.6 \pm 1.06^{*}$ \\
\hline Bryophyllum pinnatum & $48.2 \pm 1.56$ & $82.4 \pm 0.17^{*}$ & $48.3 \pm 1.05^{*}$ & $\mathrm{Nd}$ & $\mathrm{Nd}$ \\
\hline Byrsocarpus coccineus Bark & $24.6 \pm 0.99$ & $52.9 \pm 4.11^{*}$ & $43.7 \pm 1.02^{*}$ & $\mathrm{Nd}$ & $65.2 \pm 0.87^{*}$ \\
\hline Leaves & $18.6 \pm 4.85$ & $31.3 \pm 0.53^{*}$ & $29.1 \pm 0.64^{*}$ & $\mathrm{Nd}$ & $43.4 \pm 1.77^{*}$ \\
\hline Cajanus cajan & $56.1 \pm 10.09$ & $56.8 \pm 2.60$ & $50.5 \pm 0.76$ & $52 \pm 0.53$ & $\mathrm{Nd}$ \\
\hline Daniellia oliveri & $28.1 \pm 0.56$ & $153.1 \pm 1.56$ & $130.0 \pm 0.45$ & $147.0 \pm 0.47$ & $\mathrm{Nd}$ \\
\hline Erythrophleum suaveolens & $0.55 \pm 0.18$ & $0.50 \pm 0.03$ & $1.30 \pm 0.14$ & $0.80 \pm 0.11$ & $0.20 \pm 0.05$ \\
\hline Hoslundia opposita & $76.4 \pm 7.89$ & $56.1 \pm 1.57$ & $59.7 \pm 8.11$ & $\mathrm{Nd}$ & $>200$ \\
\hline Jatropa curcas & L. $21.3 \pm 0.38$ & $33.4 \pm 0.70$ & $>200$ & $>200$ & $>200$ \\
\hline Landolphia dulcis & $16.3 \pm 4.31$ & $>200$ & $>200$ & $>200$ & $\mathrm{Nd}$ \\
\hline Lannea nigritana & $48.2 \pm 3.52$ & $\mathrm{Nd}$ & $>200$ & $\mathrm{Nd}$ & $53.5 \pm 0.35^{*}$ \\
\hline Parkia biglobosa & $100.0 \pm 0.67$ & $125.0 \pm 2.21$ & $56.1 \pm 0.45$ & $136.0 \pm 0.81$ & $\mathrm{Nd}$ \\
\hline Parkia filicoidea & $149.0 \pm 2.65$ & $>200$ & $94.3 \pm 0.50$ & $\mathrm{Nd}$ & $\mathrm{Nd}$ \\
\hline Pterocarpus santalinoides & $57.9 \pm 0.35$ & $>200$ & $>200$ & $>200$ & $10.2 \pm 0.25$ \\
\hline Sida acuta & $10.3 \pm 0.21$ & $41.1 \pm 1.05$ & $37.1 \pm 0.18$ & $\mathrm{Nd}$ & $42.3 \pm 0.79$ \\
\hline Tetrapleura tetraptera & $9.1 \pm 1.40$ & $23.1 \pm 7.05$ & $\mathrm{Nd}$ & $\mathrm{Nd}$ & $37.5 \pm 5.13^{*}$ \\
\hline Vitex doniana Bark & $62.5 \pm 0.23$ & $171.1 \pm 1.33$ & $>200$ & $89.2 \pm 6.65$ & $84.0 \pm 1.13$ \\
\hline Root & $44.9 \pm 0.10$ & $152.3 \pm 1.22$ & $177.3 \pm 1.01$ & $45.6 \pm 1.35$ & $43.4 \pm 0.64$ \\
\hline
\end{tabular}

Results are expressed as mean $\pm \mathrm{SD}(\mu \mathrm{g} / \mathrm{mL})$ of three replicate experiments. $\mathrm{Nd}=$ Not determined. There was a significant difference in cell inhibition in extract-treated cultures compared with DMSO-control in all cell lines $(P<0.05)$. 
doniana with $\mathrm{IC}_{50}$ value of $62.5,84,89.2$ and $171.1 \mu \mathrm{g} /$ $\mathrm{ml}$ (against BT-549, JURKAT, SW-480 and BT-20 respectively) and the root of the same plant showed $\mathrm{IC}_{50}$ value of 152.3 and $177.3 \mu \mathrm{g} / \mathrm{ml}$ against BT-20 and PC-3. Hoslundia opposita also showed significant activity against BT-549, with an $\mathrm{IC}_{50}$ value of $76.4 \mu \mathrm{g} / \mathrm{ml}$ and the bark of Byrsocarpus coccineus showed similar activity against JURKAT with $\mathrm{IC}_{50}$ value of $65.2 \mu \mathrm{g} / \mathrm{ml}$ (Table 3).

Other cytotoxic activity in the $\mathrm{IC}_{50}$ value range from 94.3-153.1 $\mu \mathrm{g} / \mathrm{ml}$ against different cancer cell lines were also observed, these include Parkia biglobosa $\left(\mathrm{IC}_{50}\right.$ value: $125 \mu \mathrm{g} / \mathrm{ml}$ against BT-20 and $136 \mu \mathrm{g} / \mathrm{ml}$ against SW-480), Daniellia oliveri ( $\mathrm{IC}_{50}$ value: $153.1 \mu \mathrm{g} / \mathrm{ml}$ against BT-20, $130 \mu \mathrm{g} / \mathrm{ml}$ against PC-3 and $147 \mu \mathrm{g} / \mathrm{ml}$ against SW-480) and Parkia filicoidea ( $\mathrm{IC}_{50}$ value: $94.3 \mu \mathrm{g} / \mathrm{ml}$ against PC-3 and $149 \mu \mathrm{g} / \mathrm{ml}$ against BT-549).

Cajanus cajan exhibited similar cytotoxic activity against all types of cancer cell lines used, showing $\mathrm{IC}_{50}$ value between $50.5-56.1 \mu \mathrm{g} / \mathrm{ml}$, while the extracts of Allanblackia floribunda $\left(\mathrm{IC}_{50}=48.3 \mu \mathrm{g} / \mathrm{ml}\right.$ against BT-20 and $\mathrm{IC}_{50}=57.1 \mu \mathrm{g} / \mathrm{ml}$ against SW-480), Parkia biglobosa $\left(\mathrm{IC}_{50}=56.1 \mu \mathrm{g} / \mathrm{ml}\right.$ against BT-20), Pterocarpus santalinoides $\left(\mathrm{IC}_{50}=57.9 \mu \mathrm{g} / \mathrm{ml}\right.$ against $\left.\mathrm{BT}-549\right)$ and the bark of Byrsocarpus coccineus ( $\mathrm{IC}_{50}=43.7 \mu \mathrm{g} / \mathrm{ml}$ against $\mathrm{PC}-3$ and $\mathrm{IC}_{50}=52.9 \mu \mathrm{g} / \mathrm{ml}$ against BT-20) all presented moderate cytotoxic activity. Sida acuta exhibited moderate cytotoxic activity against BT-20, JURKAT and PC-3 $\left(\mathrm{IC}_{50}=41.1,42.3\right.$ and $37.1 \mu \mathrm{g} / \mathrm{ml}$ respectively), while the extract of the root of Vitex doniana exhibited similar cytotoxic activity against BT-20, SW-480 and JURKAT $\left(\mathrm{IC}_{50}=44.9,45.6\right.$ and 43.4 $\mu \mathrm{g} / \mathrm{ml}$ respectively). Other plant extracts that showed moderate cytotoxic activity include Bidens pilosa $\left(\mathrm{IC}_{50}=\right.$ $43.1 \mu \mathrm{g} / \mathrm{ml}$ against BT-549, $\mathrm{IC}_{50}=53.7 \mu \mathrm{g} / \mathrm{ml}$ against BT-20 and $\mathrm{IC}_{50}=47.7 \mu \mathrm{g} / \mathrm{ml}$ against PC-3), Lannea nigritana $\left(\mathrm{IC}_{50}=48.2 \mu \mathrm{g} / \mathrm{ml}\right.$ against BT-549 and $\mathrm{IC}_{50}=$ $53.5 \mu \mathrm{g} / \mathrm{ml}$ against JURKAT) Bryophyllum pinnatum $\left(\mathrm{IC}_{50}=48.2 \mu \mathrm{g} / \mathrm{ml}\right.$ against BT-549 and $48.3 \mu \mathrm{g} / \mathrm{ml}$ against JURKAT) and Tetrapleura tetraptera $\left(\mathrm{IC}_{50}=\right.$ $37.5 \mu \mathrm{g} / \mathrm{ml}$ against JURKAT).

The criteria of cytotoxicity activity for the crude extracts, as established by the American National Cancer Institute $\mathrm{NCI}$ ) is an $\mathrm{IC}_{50}<30 \mu \mathrm{g} / \mathrm{ml}$ in the preliminary assay [34]. Interestingly, about nine extracts showed
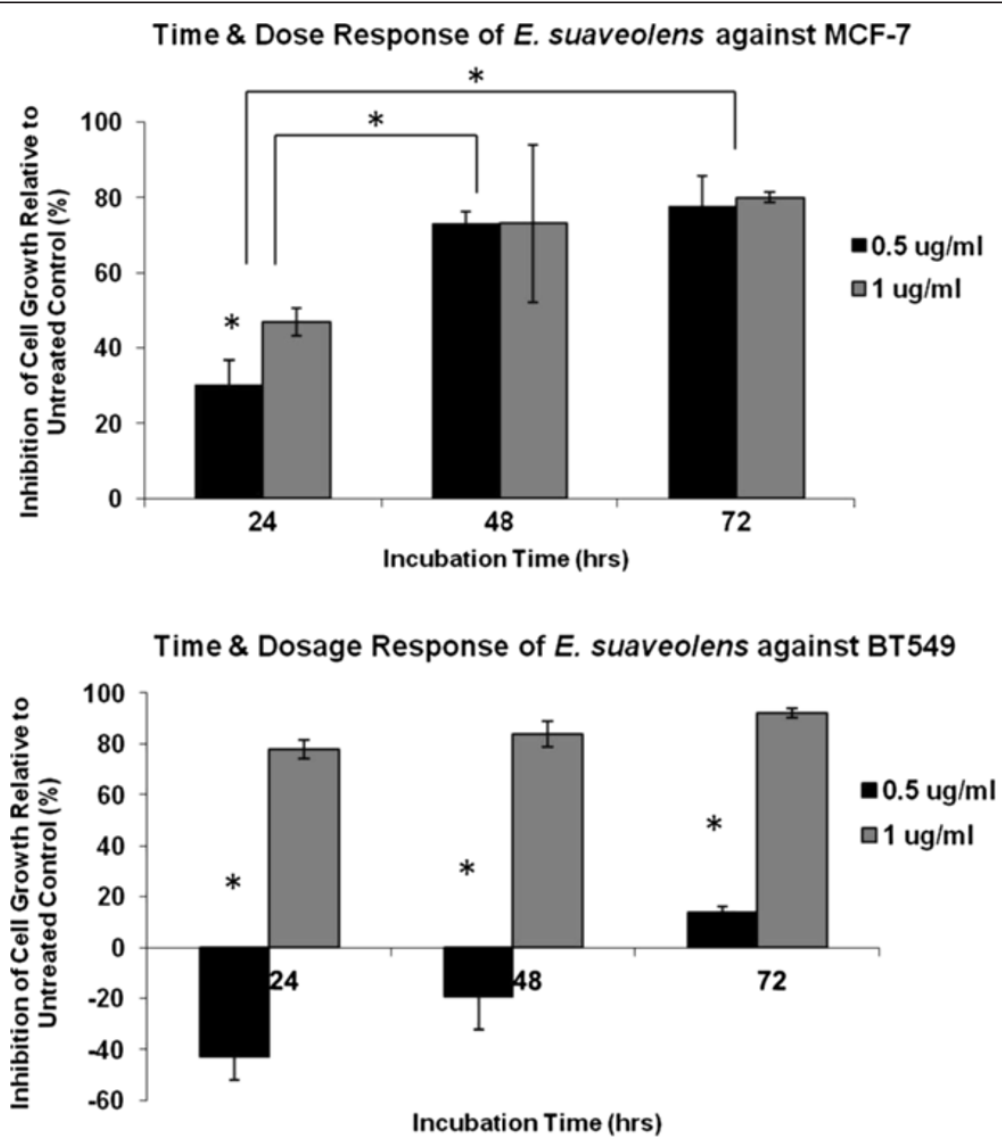

Figure 1 Time and dose response of Erythrophleum suaveolens at $0.5 \mu \mathrm{g} / \mathrm{ml}$ and $1 \mu \mathrm{g} / \mathrm{ml}$ on cell proliferation of MCF-7 and BT-549 breast cancer cell lines. Cells were plated at 10^4 cells per well in a 96-well plates and treated for 24,48 and $72 \mathrm{hr}$. Values are presented as means $(n=3) \pm$ S.D. *Statistical difference $(p<0.05)$. 
similar $\mathrm{IC}_{50}$ value close to this concentration. The extract of the leaves of Jatropha curcas exhibited cytotoxic activity against human breast adenocarcinoma cells (BT-549) with $\mathrm{IC}_{50}$ value of $21.3 \mu \mathrm{g} / \mathrm{ml}$. Similar cytotoxic activity has been previously reported, where the root of Jatropha curcas inhibits the proliferation of human colon adenocarcinoma cells $\left(\mathrm{HT}-29, \mathrm{IC}_{50}=18.3 \mu \mathrm{g} / \mathrm{ml}\right)$ and human hepatocytes cells (Chang liver, $\mathrm{IC}_{50}=33.3$ $\mu \mathrm{g} / \mathrm{ml}$ ) [35]. The extract of the leaves of Byrsocarpus coccineus also exhibited good cytotoxic activity against human breast adenocarcinoma cell lines BT-549, BT-20 and prostate adenocarcinoma cell line $\mathrm{PC}-3\left(\mathrm{IC}_{50}=18.6\right.$, 31.3 and $29.1 \mu \mathrm{g} / \mathrm{ml}$ respectively), while the bark of the same plant showed $\mathrm{IC}_{50}$ value of $24.6 \mu \mathrm{g} / \mathrm{ml}$ against BT549 (Table 3). Daniellia oliveri, Allanblackia floribunda, Sida acuta and Tetrapleura tetraptera also exhibited promising in vitro cytotoxic activity against BT-549 $\left(\mathrm{IC}_{50}=28.1,14.7,10.3\right.$ and $9.1 \mu \mathrm{g} / \mathrm{ml}$ respectively $)$. It is noteworthy to mention that a weak antitumor activity of Allanblackia floribunda has been reported using a potato disc tumor induction assay (13.9\% inhibition at 100 $\mu \mathrm{g} / \mathrm{disc}$ ) [36], while Pieme and coworkers also reported that Sida acuta inhibits the proliferation of human hepatoma cells (HepG-2) by $51.62 \%$ at $250 \mu \mathrm{g} / \mathrm{ml}$ [37].

Among plants extracts screened on multiple cell lines, four species showed a degree of selectivity. Jatropha curcas showed selective activity on breast cancer cell line $\left(\mathrm{IC}_{50}=21.3 \mu \mathrm{g} / \mathrm{ml}\right.$ against BT-549 and $\mathrm{IC}_{50}=33.4 \mu \mathrm{g} /$ $\mathrm{ml}$ against BT-20), but no activity was noticed against other types of cancer cell line (PC-3, SW-480, JURKAT). Similar selectivity for BT-549 and T-cell leukemia cell line (JURKAT) was also noticed for Daniellia oliveri $\left(\mathrm{IC}_{50}=\right.$ 28.1 and $15 \mu \mathrm{g} / \mathrm{ml}$ ). Sida acuta showed somewhat selectivity against BT-549, with $\mathrm{IC}_{50}$ value of $10.3 \mu \mathrm{g} / \mathrm{ml}$, while a pronounced selective activity was noticed for Pterocarpus santalinoides against JURKAT $\left(\mathrm{IC}_{50}=10.2 \mu \mathrm{g} / \mathrm{ml}\right)$.

The extract from the bark of Erythrophleum suaveolens exhibited the most potent activity against all types of cancer cell line used $\left(\mathrm{IC}_{50}=0.2-1.3 \mu \mathrm{g} / \mathrm{ml}\right.$, Table 3$)$ including breast cancer cells MCF-7 $\left(\mathrm{IC}_{50}=0.63 \mu \mathrm{g} / \mathrm{ml}\right)$. Earlier studies by Sowemimo and co-workers revealed that the ethanolic extract of Erythrophleum suaveolens leaves showed toxicity and mutagenic activity using brine shrimp lethality test [38].

In order to gain more insight on the mechanism of Erythrophleum suaveolens cytoxicity, it was necessary to evaluate whether the induced anticancer activity was a factor of dosage alone or dosage in correlation with time of exposure (Figure 1).

At low concentrations of Erythrophleum suaveolens a decrease of MCF-7 viability to $30 \%$ was detected after 48 $\mathrm{h}$ of exposure. As shown in Figure 1, with treatment of MCF-7, cytotoxic effects are contingent upon exposure time, which is seen by the drastic increase from $30 \%$ inhibition at $24 \mathrm{~h}$ to $80 \%$ inhibition after $72 \mathrm{~h}$. However, in BT-549 toxicity is dose dependent. No antiprolifera-
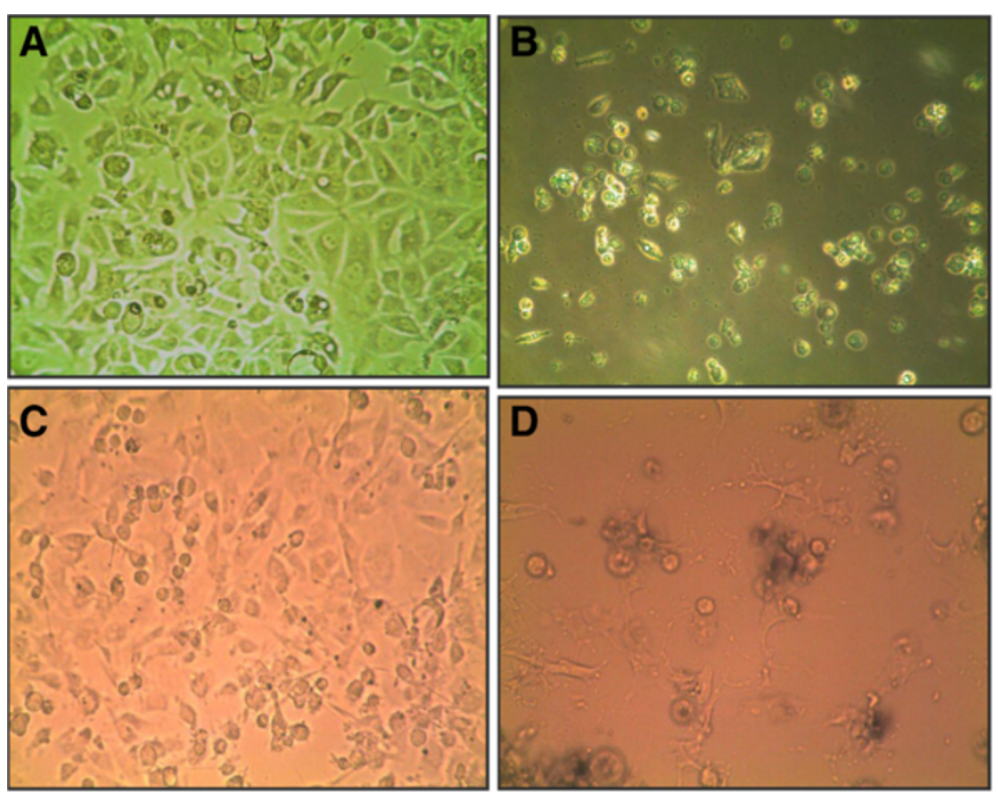

Figure 2 Microscopic images of Erythrophleum suaveolens-treated and untreated cells. (A) DMSO treated BT549 cells after $24 \mathrm{~h}$ (top left panel) (B) Detachment from culture plate (BT549) after $24 \mathrm{~h}$ exposure to Erythrophleum suaveolens at its $\mathrm{C}_{50}$ value $(0.55 \mu \mathrm{g} / \mathrm{ml}$ ), (top right panel) (C) DMSO treated BT549 cells after $48 \mathrm{~h}$ (bottom left panel) (D) Cytostatic effects after $48 \mathrm{~h}$ exposure to Erythrophleum suaveolens at its IC50 value $(0.55 \mathrm{\mu g} / \mathrm{ml})$, (right panel). All images are magnified at 40x. Images shown are representative of at least five such fields of view per sample and three replicates. 
tion effect of Erythrophleum suaveolens is detected within $48 \mathrm{~h}$ of exposure to a concentration of $0.5 \mu \mathrm{g} / \mathrm{ml}$, where in fact greater cell number is observed in treated cells. With increase in dose, at $1 \mu \mathrm{g} / \mathrm{ml}$, exposure to Erythrophleum suaveolens for $24 \mathrm{~h}$ is associated with a dramatic fall in BT-549 viability of $80 \%$.

This loss of viability increases only about $10 \%$ by $72 \mathrm{~h}$ indicating that the effects of Erythrophleum suaveolens on BT-549 are fairly rapid within a $24 \mathrm{~h}$ period. The data obtained in these preliminary studies provide enough evidence to suggest that Erythrophleum suaveolens does in fact contain potent cytotoxic compounds that inhibit tumor cells in vitro. In the crude form these active compound(s) may elicit synergistic effects or may even be subdued by the presence of other inactive components.

The time response curves reveal a peak in inhibitory activity after $18 \mathrm{~h}$ of exposure indicating that within that time frame, enough cellular damage has been inflicted to inhibit approximately $60-80 \%$ of cell viability. Physiologically, cells become detached from the base of the culture plate suggesting an interruption of the extracellular matrix and inhibition of cell to cell contact (Figure 2). Analysis with AlamarBlue indicates a complete shutdown of metabolic activity. Furthermore, microscopic comparisons between cells treated with Erythrophleum suaveolens and non-treated controls suggest cytostatic effects due the presence of active cellular expansion in controls, which is inhibited in the treated.

\section{Conclusions}

In this study 24 indigenous plants from Southwestern Nigeria were screened for their ability to induce cytotoxicity human cancer cell lines, the results of the study have therefore demonstrated that reliance on ethnomedicinal information as a strategic approach in the selection of native plants is an effective method that yields positive selection of taxonomically diverse leads with very few unfavorable candidates.

In conclusion, this study has demonstrated the successful streamlining of the screening process of bioactive plants with anticancer activity, by eliminating poor candidates on the basis of cytotoxic criterion that takes into consideration effective dosage. Results obtained from folk medicinal plants screened indicate that 18 plant extracts exhibited promising cytotoxic activity against human carcinoma cell lines. Erythrophleum suaveolens was found to demonstrate potent anti-cancer activity in this study exhibiting $\mathrm{IC}_{50}=0.2-1.3 \mu \mathrm{g} / \mathrm{ml}$. Among the active extracts, the species with the highest hit rate of demonstrated anticancer activity in this study were from the phylum Leguminosae, which is a large and economically important family of flowering plants which is commonly known as the legume family, pea family, bean family or pulse family. Extensive further analysis on the anticancer properties of Erythrophleum suaveolens compared with those of an anticancer drug compound as the positive control is currently underway. Efficacy and mechanisms of action in various normal and cancer cell models in vitro, coupled with bio-assay guided purification in order to elucidate active anticancer compound(s) from the crude extract will be reported in due course.

\section{Competing interests}

The authors declare that they have no competing interests.

\section{Authors' contributions}

SAF and ELM conceived and designed the experiments. SAF performed the cell assay experiments and analyzed the data. OO prepared the crude methanolic extracts. AA obtained and prepared the plants. SAF and OO wrote the paper. CO and ELM supervised the study and revised the manuscript. All authors read and approved the final version of the manuscript to be published.

\section{Acknowledgements}

We are thankful to the U.S. Department of Education Title III Grant, Tennessee State University, for the financial support.

\section{Author details}

${ }^{1}$ Department of Biological Sciences, Tennessee State University, 3500 John A. Merritt Blvd, Nashville, TN 37217, USA. ²Department of Chemistry, Tennessee State University, 3500 John A. Merritt Blvd, Nashville, TN 37217, USA. ${ }^{3}$ Department of Internal Medicine Meharry Medical College, 1005 Dr. D. B. Todd, Jr. Blvd, Nashville, TN 37208, USA. ${ }^{4}$ Department of Chemistry and Chemical Biology, Harvard University, 12 Oxford Street, Cambridge, MA 02138, USA. ${ }^{5}$ Department of Wildlife and Eco-tourism Management, Federal College of Wildlife Management, Forestry Research Institute of Nigeria, New Bussa, Niger State, Nigeria.

Received: 22 March 2012 Accepted: 14 March 2013 Published: 8 April 2013

\section{References}

1. Jemal A, Siegel R, Ward E, Hao Y, Xu J, Murray T, Thun MJ: Cancer statistics, 2008. CA Cancer J Clin 2008, 58:71-96.

2. Farnsworth NR: Screening plants for new medicines. In Chapter 9 in Biodiversity. Edited by Wilson EO. Washington D.C: National Academy Press; 1988.

3. Kim J, Park EJ: Cytotoxic anticancer candidates from natural resources. Curr Med Chem Anti-Canc Agents 2002, 2:485-537.

4. Mann J: Natural products in cancer chemotherapy: past, present and future. Nat Rev Cancer 2002, 2:143-148.

5. Grabley S, Thiericke R: Bioactive agents from natural sources: trends in discovery and application. Adv Biochem Engin Biotechnol 1999, 64:104-154.

6. Lee K-H: Discovery and development of natural product-derived chemotherapeutic agents based on a medicinal chemistry approach. J Nat Prod 2010, 73:500-516.

7. Gueritte F, Fahy J: The vinca alkaloids. In Anticancer Agents from Natural Products. Edited by Cragg GM, Kingston DGI, Newman DJ. Boca Raton, Florida: Taylor \& Francis Group; 2005:123-136.

8. Cragg GM: Paclitaxel $\left(\operatorname{Taxol}^{\circledR}\right)$ : a success story with valuable lessons for natural product drug discovery and development. Med Res Rev 1998, 18:315-331.

9. Lee KH, Xiao Z: Podophyllotoxins and analogs. In Anticancer Agents from Natural Products. Edited by Cragg GM, Kingston DGI, Newman DJ. Boca Raton, Florida: Taylor \& Francis Group; 2005:71-88.

10. Rahier NJ, Thomas CJ, Hecht SM: Camptothecin and its analogs. In Anticancer Agents from Natural Products. Edited by Cragg GM, Kingston DGl, Newman DJ. Boca Raton, Florida: Taylor \& Francis Group; 2005:5-22.

11. Prance GT, Beentje H, Dransfield J, Johns R: The tropical flora remains under collected. Ann Missouri Bot Gard 2000, 87:67-71.

12. Govaerts R: How many species of seed plants are there? Taxon 2002, 50:1085-1090. 
13. Taylor JLS, Rabe T, McGaw LJ, Jäger AK, van Staden J: Towards the scientific validation of traditional medicinal plants. Plant Growth Regul 2001, 34:23-37. and refrence herewith in.

14. Bramwell D: How many plant species are there? Plant Talk 2002, 28:32-34.

15. Cordell GA, Beecher CW, Pezzuto JM: Can enthnopharmacology contribute to the development of new anticancer drugs? J Ethnopharmacol 1991 32:117-133

16. Gbile ZO, Adesina SK: Nigerian flora and it's pharmaceutical potential. J Ethnopharmacol 1987, 19:1-16.

17. Igoli JO, Ogaji TA, Tor-Ayin, Igoli NP: Traditional medicine practice amongst the igede people of Nigeria. Part II. Afr J Trad CAM 2005, 2:134-152.

18. Kayode J: Conservation of indigenous medicinal botanicals in Ekiti State, Nigeria. J Zhejiang Univ Science B 2006, 7:713-718.

19. Gbolade AA: Inventory of antidiabetic plants in selected districts of Lagos State, Nigeria. J Ethnopharmacol 2009, 121:135-139.

20. Mudi SY, Ibrahim H: Activity of Bryophyllum Pinnatum S. Kurz extracts on respiratory tract pathogenic bacteria. Bayero J Pure App/ Sci 2008, 1:43-48.

21. Burkill HM: Useful plants of West Tropical Africa, Volume 1. 2nd edition. Families A-D, Royal Botanic; 1985.

22. Dongmo AB, Kamanyi A, Anchang MS, Chungag-AnyeNkeh B, Njamen D, Nguelefack TB: Anti-inflammatory and analgesic properties of the stem bark of Erythropleum suaveolens (Ceasalpiniaceae) Guillemin and Perrottet. J Ethnopharmacol 2001, 77:137-141. and refrence herewith in.

23. Oladele AT, Adewunmi CO: Medicinal plants used in the management of malaria among the traditional medicine practitioners (TMP'S) in south western Nigeria. Afr J Infect Dis 2008, 2:51-59.

24. Dairo FAS, Adanlawo IG: Nutritional Quality of Crassocephalum crepidioides and Senecio biafrae. Pak J Nutr 2007, 6:35-39.

25. Ajibade LT, Fatoba PO, Rahemm UA, Odunuga BA: Ethnomedicine and Primary Healthcare in Ilorin. Nigeria Indian J Trad Knowl 2005, 4:150-158.

26. Usman LA, Zubair MF, Adebayo SA, Olados IA, Muhammad NO, Akolade JO: Chemical Composition of Leaf and Fruit Essential Oils of Hoslundia opposita Vahl Grown in Nigeria. American-Eurasian J Agric Environ Sci 2010, 8:40-43.

27. Akharaiyi FC: Boboye Bolatito: Antibacterial and Phytochemical Evaluation of Three Medicinal Plants. J Nat Prod 2010, 3:27-34.

28. Strober W: Trypan blue exclusion test of cell viability. Curr Protoc Immun 1997, 3:1-2.

29. Adeleke MA, Popoola SA, Agbaje WA, Adewale B, Adeoye MD, Jimoh WA: Larvicidal efficacy of seed oils of Pterocarpus santalinoides and Tropical Manihot species against Aedes aegypti and effects on aquatic fauna. Tanzan J Health Res 2009, 11:250-252.

30. Osuagwu GGE, Okwulehie IC, Emenike JO: Phytochemical and mineral content of the leaves of four Nigerian Pterocarpus 9JACQ) species. Int J Mol Med Adv Sci 2007, 3:6-11.

31. Aiyeloja AA, Bello OA: Ethnobotanical potentials of common herbs in Nigeria: A case study of Enugu state. Edu Res Rev 2006, 1:16-22.

32. Kilani AM: Antibacterial assessment of whole stem bark of Vitex doniana against some enterobactriaceae. Afr J Biotechnol 2006, 5:958-959.

33. Voytik-Harbin SL, Brightman AO, Waisner B, Lamar CH, Badylak SF: Application and evaluation of the alamarblue assay for cell growth and survival of fibroblasts. In Vitro Cell. Dev. Biol-Animal 1998, 34:239-246.

34. Suffness M, Pezzuto JM: Assays related to cancer drug discovery. In Methods in Plant Biochemistry: Assays for Bioactivity. Edited by Hostettmann K. London: 6: Academic Press; 1990:71-133.

35. Oskoueian E, Abdullah N, Saad WZ, Omar AR, Ahmad S, Kuan WB, Zolkifli NA, Hendra R, Ho YW: Antioxidant, anti-inflammatory and anticance activities of methanolic extracts from Jatropha curcas Linn. J Med Plants Res 2011, 5:49-57.

36. Kuete $V$, Azebaze AGB, Mbaveng AT, Nguemfo EL, Tshikalange ET, Chalard P, Nkengfack AE: Antioxidant, antitumor and antimicrobial activities of the crude extract and compounds of the root bark of Allanblackia floribunda. Pharm Biol 2011, 49:57-65.
37. Pieme CA, Penlap VN, Ngogang J, Costache M: In vitro cytotoxicity and antioxidant activities of five medicinal plants of Malvaceae family from Cameroon. Environ Toxicol Pharmacol 2010, 29:223-228.

38. Sowemimo AA, Fakoya FA, Awopetu I, Omobuwajo OR, Adesanya SA: Toxicity and mutagenic activity of some selected Nigerian plants. J Ethnopharmacol 2007, 113:427-432.

doi:10.1186/1472-6882-13-79

Cite this article as: Fadeyi et al:: In vitro anticancer screening of 24 locally used Nigerian medicinal plants. BMC Complementary and

Alternative Medicine 2013 13:79.

\section{Submit your next manuscript to BioMed Central and take full advantage of:}

- Convenient online submission

- Thorough peer review

- No space constraints or color figure charges

- Immediate publication on acceptance

- Inclusion in PubMed, CAS, Scopus and Google Scholar

- Research which is freely available for redistribution

Submit your manuscript at www.biomedcentral.com/submit
C Biomed Central 